\title{
Implementation of government support measures for reclamation as an incentive for the development of the agricultural industry: Experience of the Republic of Tatarstan
}

\author{
Marsel Khismatullin ${ }^{1, *}$, Farit Mukhametgaliev ${ }^{1}$, Nail Asadullin $^{1}$, Fayaz Avkhadiev $^{1}$, Mars Khismatullin ${ }^{2}$ and Ullah \\ Raheem ${ }^{1}$ \\ ${ }^{1}$ Kazan State Agrarian University, Kazan, 420015, Russia \\ 2 FSBI "Management" Tatmeliovodkhoz", Kazan, 420073, Russia
}

\begin{abstract}
The article discusses the issue of government support for reclamation activities in the context of new challenges of the economic environment. The relevance of the issue is due to the need for intensive development of the agricultural sector caused by globalization processes, which have created fierce competition, both in the international and domestic food markets. Sustainable production of agricultural products on irrigated lands is one of the main indicators of the efficiency of the agro-industrial complex in areas of risky agriculture, including the Republic of Tatarstan. The purpose of the article is to develop recommendations for improving the efficiency of irrigated agriculture whose development depends on the stability of agricultural production and food security. The study aims to identify trends in the development of land reclamation at the regional level and substantiate measures aimed to improve the economic efficiency. The paper presents results of the analysis of development of land reclamation in the Republic of Tatarstan, identifies directions of its development, provides recommendations for ensuring sustainable growth in the volume of reclaimed land and agricultural products, income from the sale of products obtained through irrigation. The research results can be used to develop programs aimed at the development of federal and regional food markets, organizational, economic, technological measures to improve the efficiency of agricultural production, rural areas and the provision of high-quality food supply to the population.
\end{abstract}

\section{Introduction}

There are irrigated lands in more than 100 countries which are the basis for ensuring food security of any state, including the Russian Federation.

In the developed countries, the share of reclaimed lands is 50 percent. In Russia, their share does not exceed 10 percent, and in the Republic of Tatarstan, it is 7 percent. Meanwhile, land reclamation is a more progressive scientific and technical direction of agricultural production, which enhances the human impact, aimed at regulating external factors in the formation of highly productive agrocenoses [1-3]. The development of water reclamation also contributes to the solution of a number of socio-economic problems of rural areas.

However, as a result of the institutional transformations carried out in the agrarian sector of the Russian economy in the 1990s, the land reclamation of territories of rural settlements of the Republic of Tatarstan bcame worse. At the end of the 1980s, more than 245 thousand hectares of land were occupied by irrigated agriculture which made it possible to provide livestock with fodder and receive up to 65 c.u. units per hectare.

Therefore, radical transformations of agricultural production based on reforms of the agro-industrial complex require a different approach to the use of all lands, including irrigated ones, taking into account the comprehensive assessment of this process.

On the other hand, along with land reclamation, it is necessary to take into account environmental, economic, social issues aimed at producing products in a more rational way with strict observance of environmental protection measures [2].

\section{Materials and Methods}

The research is based on the theoretical and methodological basis, which makes it possible to use possibilities of interaction and complementarity of the fundamental provisions and concepts of land reclamation science. The theoretical and methodological base is works by foreign and domestic scientists and reclamation practitioners [4-7], international and domestic rules governing the relations arising in the reclamation process and materials international and

\footnotetext{
Corresponding author: marselmansurovic@ mail.ru
} 
national scientific and practical conferences intended to provide answers to the challenges of the agro-industrial complex.

The methodological basis of the research is the system analysis. The extensive material has caused the need to use various approaches, methods and techniques: constructive, deterministic, retrospective, dynamic, and statistical methods.

The methods were used to reveal the trends in the development of agri-food policy and peculiarities of their manifestation: monographic, abstract-logical, calculation-constructive, economic and statistical, analogies.

As an information base, official data of the Federal State Statistics Service, the Ministry of Agriculture of the Russian Federation, the Ministry of Agriculture and Food of the Republic of Tatarstan, the Federal State Institution "Tatmeliovodkhoz Management", planning and reporting documents of agricultural organizations, monographs, dissertations, reports of research institutes, materials of scientific conferences, expert assessments were used.

\section{Results}

The Republic of Tatarstan is located in the zone of risky farming, and the natural potential of its arable land is only $2.5 \mathrm{t} /$ ha of grain units.

Nevertheless, due to efficient field works, adherence to the technological cycle, and the built-up process of crop production management in 2020, 5.5 million tons of grain, 2.1 million tons of sugar beet, 1.5 million tons of potatoes and vegetables were produced, which is 3 times higher that the average indicator.

After the abnormal drought of 2010, serious attention has been paid to the reclamation complex. Irrigation is also becoming more in demand for farms with developed livestock breeding and a high density of livestock, since the development of the reclamation complex is one of the priority areas for the development of the regional agro-industrial complex.

Over 4.2 billion rubles have been invested for the implementation of reclamation measures in the Republic of Tatarstan (Table 1).

Table 1. Dynamics of the volume of attracted financial resources for performing reclamation works within the targeted programs for the development of reclamation, mln. Rubles.

\begin{tabular}{|c|c|c|c|c|c|c|c|}
\hline $\begin{array}{c}\text { Sources of } \\
\text { funding }\end{array}$ & $\mathbf{2 0 1 5}$ & $\mathbf{2 0 1 6}$ & $\mathbf{2 0 1 7}$ & $\mathbf{2 0 1 8}$ & $\mathbf{2 0 1 9}$ & $\mathbf{2 0 2 0}$ & $\begin{array}{c}\text { Total } \\
\text { for six } \\
\text { years }\end{array}$ \\
\hline Federal budget & 168 & 108 & 240 & 228 & 240 & 331 & 1315 \\
\hline $\begin{array}{c}\text { Republican } \\
\text { budget }\end{array}$ & 460 & 519 & 498 & 450 & 386 & 591 & 2904 \\
\hline Total & 628 & 628 & 739 & 678 & 627 & 922 & 4222 \\
\hline
\end{tabular}

Over this period, 32.2 thousand hectares of irrigated land were restored, 450 hydraulic structures (GTS) were repaired, 131 water wells were drilled, 44 water towers were installed (Fig. 1).

During the implementation of the presidential program aimed at the overhaul of the hydraulic system, more than 450 ponds out of the existing 887 structures were brought into the standard technical condition (Fig. 2), they accumulate 109 million $\mathrm{m}^{3}$ of water.
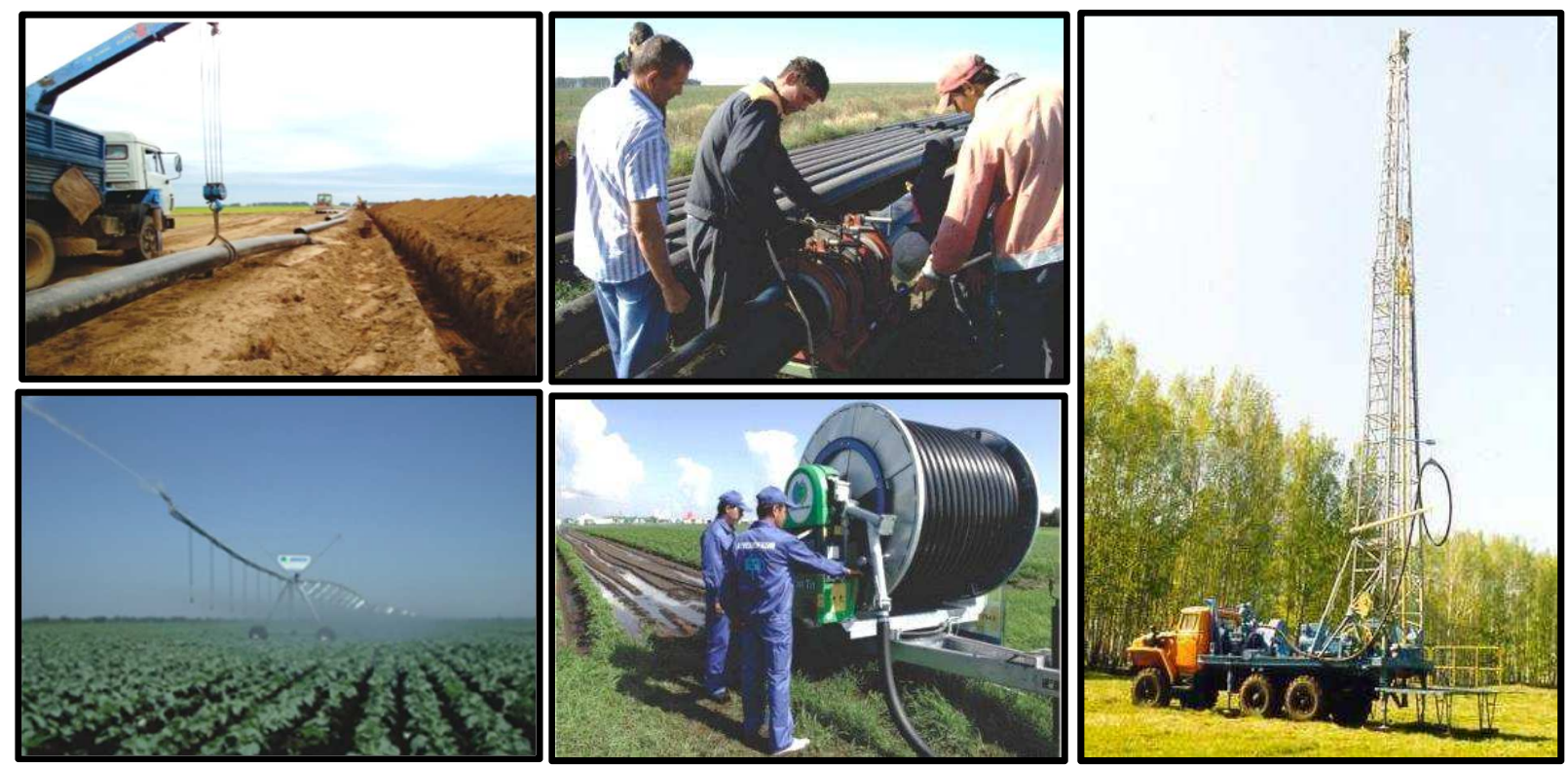

Fig. 1. Construction of infrastructure facilities for amelioration

An invaluable advantage of the land reclamation is that during the years of hasty and thoughtless reforms, due to the joint efforts of the Ministry of Agriculture and Food, land reclamation departments and highly qualified personnel have been preserved [8-10].
Currently, more than 40 enterprises conduct successful land reclamation activities, employing about 2 thousand qualified specialists and workers.

The federal institution Tatmeliovodkhoz subordinate to the Ministry of Agriculture of the Russian Federation 
performs construction, installation and maintenance works on land reclamation. More than 3 thousand hectares of irrigated lands are being commissioned, more than 30 water wells are being drilled. In 2020 alone, reclamation units performed repair and construction works at 128 reclamation facilities.

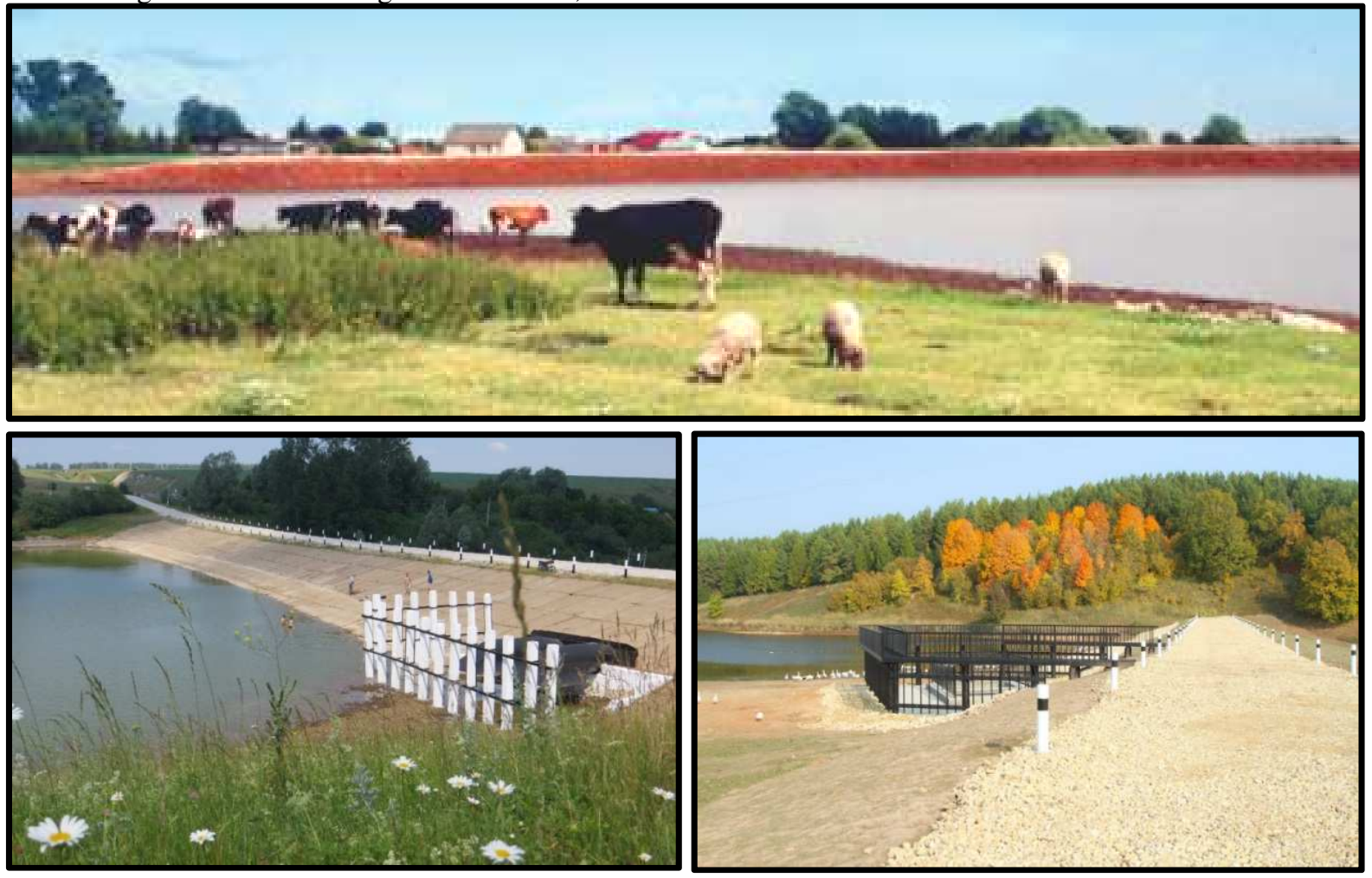

Fig. 2. Restored hydraulic structures in the Republic of Tatarstan

Within the federal targeted program, 4 large federal reclamation facilities with a total area of 2270 hectares were built. The total cost of the facilities is 270 million rubles.

Positive opinios of the state examination were received for projects intended at the reconstruction of 6 federal objects on an area of 3098 hectares, (reconstruction of the Muslyumovskaya, Zainskaya, Laishevskaya, Sabinskaya, Pyatiletka, Tumutuk irrigation systems), flood control measures in the amount of 17 million rubles were implemented at five federal facilities.

Within the departmental program "Development of the land reclamation complex in Russia", 241 million rubles were spent (Table 2), which made it possible to introduce new irrigated lands on an area of 2.9 thousand hectares, to implement cultural and technical measures on an area of 300 hectares, to lime over 80 thousand hectares of acidic soils.

In the Republic of Tatarstan, within the federal project "Export of agricultural products" due to the development of hydro reclamation and technical reequipment of irrigated lands, 1,220.5 hectares of irrigated land were introduced in 2020 (Table 3).

As part of the federal programs and projects, more than 6.2 thousand hectares of irrigated land were commissioned.
Table 2. Reclamation works co-financed from the federal budget under the federal target program and the departmental program in 2020 in the Republic of Tatarstan

\begin{tabular}{|c|c|c|}
\hline $\begin{array}{c}\text { Types of reclamation } \\
\text { works }\end{array}$ & $\begin{array}{c}\text { Volume of } \\
\text { works, } \\
\text { million rubles }\end{array}$ & $\begin{array}{c}\text { thousand } \\
\text { hectares }\end{array}$ \\
\hline $\begin{array}{c}\text { Subsidy for reclamation } \\
\text { works, including: }\end{array}$ & 241.0 & \\
\hline $\begin{array}{c}\text { irrigation and drainage } \\
\text { activities (2147 ha) 70/30 }\end{array}$ & 147.1 & 2.9 \\
\hline $\begin{array}{c}\text { cultural and technical } \\
\text { activities (300 ha) 70/30 }\end{array}$ & 8.2 & 0.3 \\
\hline agroforestry activities 90/10 & 15.6 & 2.8 \\
\hline liming measures & 70.0 & 80.0 \\
\hline
\end{tabular}

Table 3. Parameters of implementation of the National project "Export of products of the agro-industrial complex" in the Republic of Tatarstan 2019-2022.

\begin{tabular}{|c|c|c|c|c|}
\hline Years & $\begin{array}{c}\text { Total, } \\
\text { RUB } \\
\text { million }\end{array}$ & $\begin{array}{c}\text { Indicator, } \\
\text { ha }\end{array}$ & $\begin{array}{c}\text { Performance, } \\
\text { ha }\end{array}$ & $\begin{array}{c}\text { Performance, } \\
\text { \% }\end{array}$ \\
\hline 2019 & 38.6 & 500 & 705 & 141 \\
\hline 2020 & 72.6 & 1000 & 1220 & 122 \\
\hline 2021 & 74.7 & 1000 & - & - \\
\hline 2022 & 91.3 & 1000 & - & - \\
\hline Total & 277.2 & 3500 & 1925 & - \\
\hline
\end{tabular}

The specified achievements would be impossible if the Republic of Tatarstan did not have scientific, technical and production potential. In Vysokogorsk region, Kazan Irrigation Equipment Plant with a 
production base on an area of $24000 \mathrm{~m}^{2}$, an area of production premises of $2164 \mathrm{~m}^{2}$, a warehouse area of $4200 \mathrm{~m}^{2}$, an area of the administrative building of 1000 m2 was built (Fig. 3). Modern wide-grip sprinklers are produced there, which provides a serious advantage for
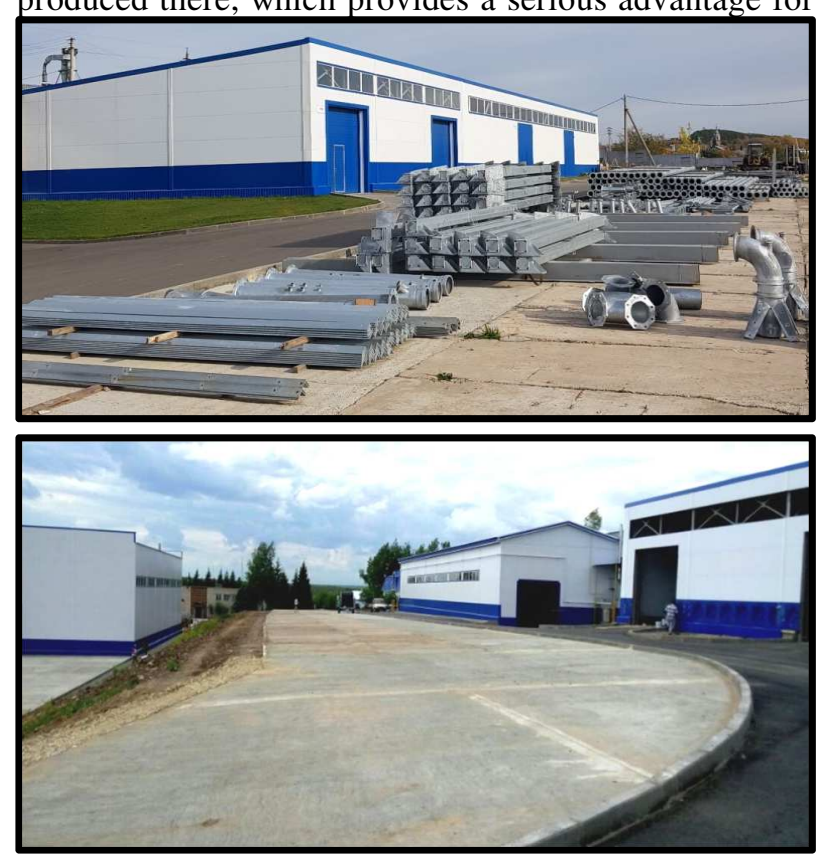

Fig. 3. General view of the Kazan irrigation equipment

Table 4. Implementation of the Republican Melioration Program in 2020 (without co-financing from the Russian Federation)

\begin{tabular}{|c|c|c|c|}
\hline Measures & $\begin{array}{c}\text { Total, } \\
\text { million } \\
\text { rubles. }\end{array}$ & $\begin{array}{c}\text { Budget of the } \\
\text { Republic of } \\
\text { Tatarstan, } \\
\text { mln., Rubles }\end{array}$ & $\begin{array}{c}\text { Extra- } \\
\text { budgetary } \\
\text { sources } \\
\text { mln., Rub. }\end{array}$ \\
\hline Total in all directions & 525.5 & 476.0 & 49.5 \\
\hline including & & & \\
\hline overhaul, (100\%) & 190.0 & 190.0 & \\
\hline $\begin{array}{c}\text { Subsidy for the } \\
\text { purchase of reclamation } \\
\text { equipment) (70/30) }\end{array}$ & 142.9 & 100.0 & 42.9 \\
\hline $\begin{array}{c}\text { Well drilling subsidy } \\
\text { (90/10) }\end{array}$ & 39.7 & 36.0 & 6.7 \\
\hline $\begin{array}{c}\text { Agroforestry activities } \\
100 \%\end{array}$ & 150.0 & 150.0 & \\
\hline
\end{tabular}

The the plant has produced and installed more than 150 sprinkler machines, which operate in the fields of Tatarstan and other regions of Russia: the Altai region, the Republic of Mari El, the Republic of Udmurtia.

In addition to the federal programs, 5 directions of land reclamation are being implemented at the expense the republic both in the Volga Federal District and in the Russian Federation as a whole. In 2016, the production of circular wide-coverage irrigation systems "Kazanka" with a working length of 60 to 600 meters was launched.

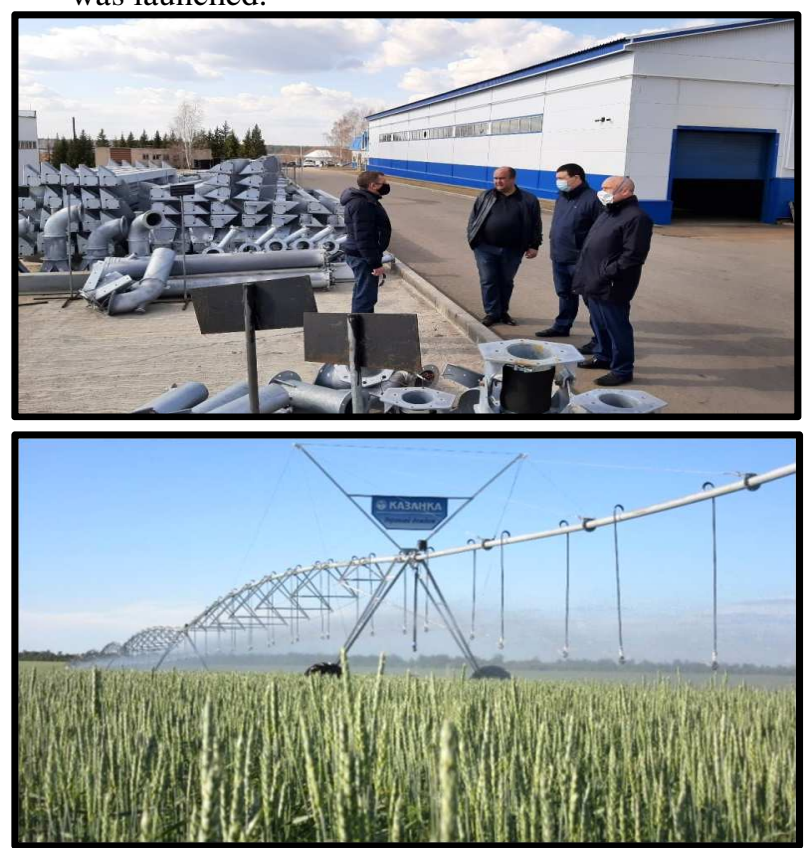

of the regional budget. In 2020, under the republican target program, 525 million rubles were spent on the land reclamation (Table 4).

The Republic finances $100 \%$ of the cost for capital repairs of the equipment. In 2020, the volume of funding was 190 million rubles, which contributed to the repair of more than 40 facilities.

The technical re-equipment of land reclamation facilities is subsidized by the budget of Tatarstan by $70 \%$, which provides for the purchase of modern sprinkler and pumping equipment, including drip irrigation systems. In 2020, 100 million rubles were allocated for these purposes.

As part of the Republican program, subsidies are provided to farms to cover $90 \%$ of the cost of drilling water wells. In 2020, the volume of funding was 36 million rubles: 21 wells were drilled and 8 water towers were installed.

Within the agroforestry, more than 2.8 thousand hectares of protective forest belts are introduced annually (Fig. 4). 


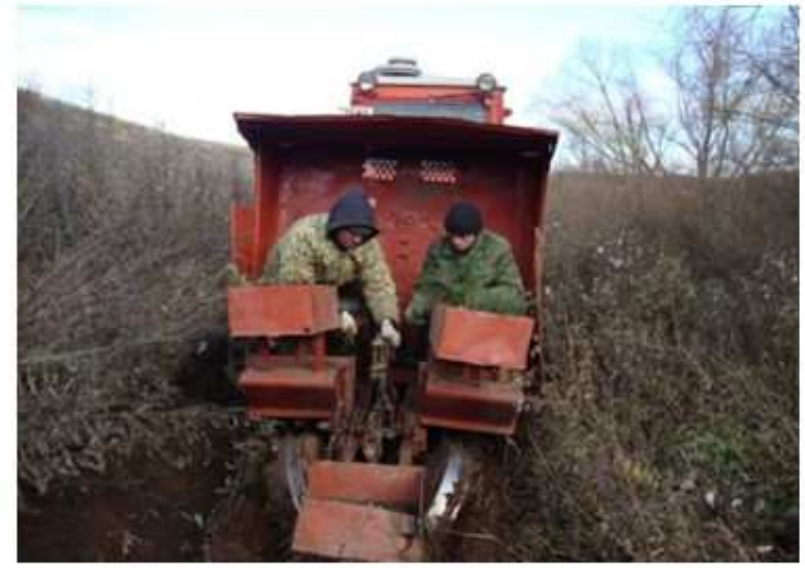

Fig. 4. Agroforestry activities in the Republic of Tatarstan

\section{Conclusion}

Modern irrigated agriculture is a high-cost and high-tech production; however, the use of reclamation technologies allows companies to increase the yield of agricultural crops more than 2-3 times and serves as a guarantor of the stability of agricultural production. Due to the irrigation, the average yield for potatoes is up to $40 \mathrm{t} / \mathrm{ha}$; vegetables - $70 \mathrm{t} / \mathrm{ha}$; fodder $-40 \mathrm{t} / \mathrm{ha}$; it is higher (3-4 times) than on dry land even in favorable weather conditions.

When watering, the cost of production is 2 or more times lower than on dry lands. For 1 ruble of direct costs for irrigation, it provides additional products worth more than 12 rubles. This is clear evidence that land reclamation is the very lever that ensures the national food security.

Due to the high-tech and high-cost of reclamation measures, the low technical level of reclamation systems, the physical wear of the existing reclamation infrastructure, engineering structures, insufficient number of irrigation equipment, violations of irrigation technology and crop cultivation, a deterioaration in soil fertility, the results of the industry are not as high as they could be. Currently, the overwhelming majority of agricultural organizations and small farms lack resources. For the development of the reclamation industry, it is necessary to strengthen the role of the government. It is necessary to improve the regulatory and technical base in the field of irrigation and drainage, which determines criteria and indicators of efficiency, reliability and safety of reclamation systems and hydraulic structures [11-13].

In order to develop new and update existing state and industry standards on land reclamation, it is necessary to develop the Technical regulations on land reclamation for agricultural purposes.

New challenges require a transition to a new stage of irrigated agriculture, which requires new knowledge, innovative irrigation technologies, technical and technological means, new intensive varieties and hybrids, fertilizer-stimulating compositions, modern

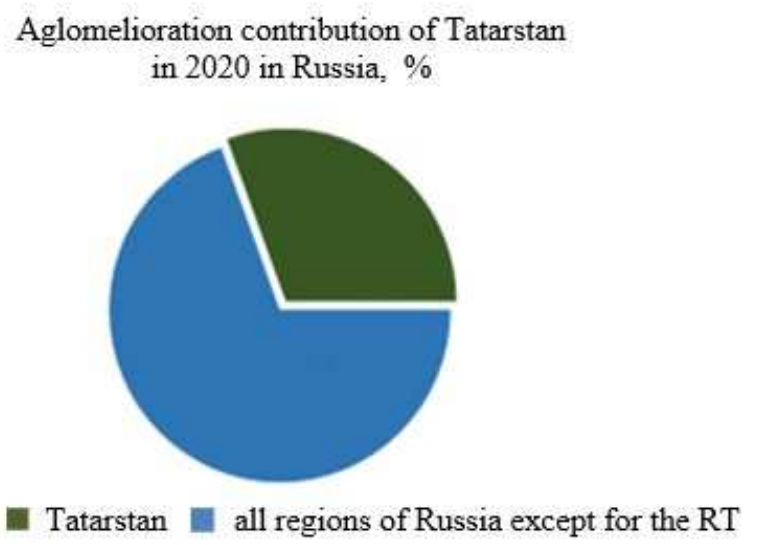

organo-mineral nutrient solutions containing easily assimilated amino acids, chelated forms of micronutrient fertilizers and biological preparations, scientific and personnel support for the land reclamation. The key role should be assigned to Kazan State Agrarian University, whose team has more than 100 years of experience in training hydro-meliorators, forest meliorators, hydrobuilders, land surveyors, engineers, machine operators and other specialists. The agrarian university has staff, scientific, methodological and material and technical base, which must be preserved, supported and improved [14-16].

\section{References}

1. I.A. Kayumov, M.M. Khismatullin, Euras. Sci. Associat., 1(7(29)), 70-72 (2017)

2. A.V. Pomorov (Ph.D. Dissertation) (2005), pp. 1-173.

3. A.K. Nosov (Cand. dissertation thesis) (2009), pp. 1-25

4. On the approval of economically significant regional programs, Resolution of the Cabinet of Ministers of the Republic of Tatarstan dated 25.07.2011, no. 580

5. Development of agriculture and regulation of markets for agricultural products, raw materials and food in the Republic of Tatarstan for 20132020 , On the results of the implementation of the State program in terms of the development of agricultural land reclamation and plans until 2020

6. F.N. Safiollin, M.M. Khismatullin, The system of land reclamation in the Republic of Tatarstan (2015), 310 p.

7. A.K. Subaeva, N.M. Yakushkin, M.M. Nizamutdinov, L.M. Mavlieva, J. Public, 12(1), 568-577 (2017)

8. A.K. Subaeva, V.T. Vodyannikov, E.V. Khudyakova, D.I. Dorodnykh, J. of Fundam. and Appl. Sci., 10(4S), 1151-1159 (2018) 
9. F.N. Mukhametgaliev, D.F. Khafizov, M.M. Khismatullin, I.G. Gainutdinov, L.F. Sitdikova, Bull. of Kazan State Agrar. Univ., 1(52), 138-144 (2019)

10. F.N. Mukhametgaliev, L.F. Sitdikova, M.M. Khismatullin, N.M. Asadullin, L.V. Mikhailova, BIO Web of Conf., 17, 00083 (2020)

11. M.M. Khismatullin, L.T. Vafina, F.N. Safiollin, IOP Conf. Ser. Earth and Envir. Sci., 012109 (2019)

12. F.N. Avkhadiev, F.N. Mukhametgaliev, L.F. Sitdikova, F.F. Mukhametgalieva, Stud. on Russ. Econ. Devel., 30(2), 162-165 (2019)
13. F.N. Avkhadiev, F.N. Mukhametgaliev, L.F. Sitdikova, I.G. Gainutdinov, BIO Web of Conf., 17, 00082 (2020)

14. G.S. Klychova, A. Zakirova, I. Safiullin, Z. Zakirov, Sh. Khusainov, G. Zakharova, E3S Web of Conf., 08013 (2020)

15. M. Faskhutdinova, E. Amirova, I. Safiullin, L. Ibragimov, BIO Web of Conf., 27, 00020 (2020)

16. A. Belinsky, B. Ziganshin, A. Valiev, D. Haliullin, I. Galiev, N. Adigamov, Engin. for Rural Develop., 206-213 (2019) 